\title{
Suppression of Pituitary TSH Secretion in the Patient with a Hyperfunctioning Thyroid Nodule
}

\author{
E. C. Ridgway, B. D. Weintraub, J. L. Cevallos, M. C. Rack, and \\ F. MaLOOF \\ From the Department of Medicine at the Massachusetts General Hospital and \\ Harvard Medical School, Boston, Massachusetts 02114
}

A в S T R A C T 10 patients with a single hyperfunctioning thyroid nodule each were studied for pituitary thyrotropin (TSH) suppression. They were judged to be euthyroid on clinical grounds. The total thyroxine $\left(\mathrm{T}_{4} \mathrm{D}\right)$, free thyroxine $\left(\mathrm{FT}_{4}\right)$, total triiodothyronine $\left(\mathrm{T}_{3} \mathrm{D}\right)$, and free triiodothyronine $\left(\mathrm{FT}_{3}\right)$ were normal in most of the patients. Incorporation of ${ }^{131} \mathrm{I}$ into the hyperfunctioning thyroid nodules was not suppressed by the administration of physiological doses of $\mathrm{T}_{\mathbf{s}}$. Basal serum $\mathrm{TSH}$ concentrations were undetectable $(<0.5-1.0 \mu \mathrm{U} /$ $\mathrm{ml})$ in all patients. The metabolic clearance of $\mathrm{TSH}$ in one patient before and after excision of the thyroid nodule was unchanged ( $40 \mathrm{vs} .42 \mathrm{ml} / \mathrm{min}$ ) whereas the calculated production rate was undetectable before the operation ( $<29 \mathrm{mU} /$ day) and normal after $(103 \mathrm{mU} /$ day). These data, in one patient, suggest that the undetectable concentration of TSH in these patients is a result of suppressed TSH secretion rather than accelerated TSH clearance.

In eight patients, basal serum $\mathrm{TSH}$ concentrations failed to increase after the intravenous administration of $200 \mu \mathrm{g}$ of thyrotropin-releasing hormone (TRH) ; minimal increases in serum TSH concentrations were observed in two patients. The suppression of $\mathrm{TSH}$ was evident despite "normal" concentrations of circulating thyroid hormones. The observation that normal serum concentrations of $\mathrm{T}_{4} \mathrm{D}, \mathrm{FT}_{4}, \mathrm{~T}_{3} \mathrm{D}$, and $\mathrm{FT}_{3}$ may be associated with undetectable basal serum TSH concentrations and suppressed TSH response to TRH was also found in four hypothyroid patients given increasing doses of L-thyroxine and sequential TRH stimulation tests.

This work was presented in part at the IV International Congress of Endocrinology, June 18-24, 1972, in Washington, D. C.

Received for publication 1.3 December 1972 and in revised form 28 June 1973.

\section{INTRODUCTION}

It has been assumed, on the basis of anatomical (1) and physiological data $(2,3)$, that the hyperfunctioning thyroid nodule functions independently of pituitary thyroidstimulating hormone (TSH). ${ }^{1}$ We have recently studied 10 patients with hyperfunctioning thyroid nodules in an attempt to define the basal concentrations of serum $\mathrm{TSH}$ as well as the pituitary reserve of TSH after the administration of thyrotropin-releasing hormone (TRH).

\section{METHODS}

Patients. 10 patients, each with a single hyperfunctioning thyroid nodule, were studied. They were judged to be euthyroid on clinical grounds. The patients had been followed for 2-15 $\mathrm{yr}$ before study without any antithyroid therapy. For comparative data of basal TSH serum concentrations and the response of pituitary TSH to TRH, similar studies were performed on the following groups of patients. There were 56 controls, who were judged euthyroid by clinical assessment; 11 of these were studied in detail, with a correlation of serum total thyroxine $\left(T_{4} D\right){ }^{2}$ free thyroxine $\left(F T_{4}\right)$, total triiodothyronine $\left(T_{3} D\right)$, basal serum TSH, and TSH response to TRH. There were 11 hyperthyroid patients as judged by a classical clinical presentation, elevated serum $\mathrm{T}_{4} \mathrm{D}, \mathrm{FT}_{4}, \mathrm{~T}_{3} \mathrm{D}$, and radioiodine (RAI) uptake. There were four patients with primary hypothyroidism as documented by low $\mathrm{T}_{4} \mathrm{D}, \mathrm{FT}_{4}, \mathrm{~T}_{3} \mathrm{D}$, and an elevated serum TSH concentration. Three of the patients, M. S., M. Q., and L. L., had Hashimoto's thyroiditis, proved by a thyroid biopsy, and one (J. S.) had had a subtotal thyroidectomy for hyperthyroidism $15 \mathrm{yr}$ previously. Each of these four patients was given sodiumL-thyroxine (Synthroid, Flint, Eaton \& Co., Morton Grove, III.) orally, starting at 50 or $100 \mu \mathrm{g}$; then the dose was

\footnotetext{
${ }^{1}$ Abbreviations used in this paper: MCR, metabolic clearance rate; RAI radioiodine; TRH, thyrotropin-releasing hormone; TSH, thyroid-stimulating hormone.

${ }^{2}$ Abbreviation of total thyroxine $\left(T_{4} D\right)$, free thyroxine $\left(\mathrm{FT}_{4}\right)$, total triiodothyronine $\left(\mathrm{T}_{8} \mathrm{D}\right)$, free triiodothyronine $\left(\mathrm{FT}_{3}\right)$, and dialyzable $\mathrm{T}_{3}\left(\% \mathrm{FT}_{3}\right)$ are those recommended by The American Thyroid Association (4).
} 
increased gradually every $4 \mathrm{wk}$. Before each incremental increase in the L-thyroxine dosage, the patients had a TRH stimulation test in an attempt to correlate pituitary TSH suppression with circulating levels of $T_{4} \mathrm{D}, \mathrm{FT}_{4}, \mathrm{~T}_{3} \mathrm{D}$, and RAI uptake.

$T S H$ radioimmunoassay. The TSH radioimmunoassay was a modification of the method of Odell, Wilber, and Utiger (5) and similar to that recently reported by Patel, Burger, and Hudson (6). Purified human thyrotropin for labeling and rabbit anti-human thyrotropin serum were obtained from the National Pituitary Agency. Human thyrotropin research standard $B$, used as the primary standard for these assay, was obtained from the Medical Research Council, Mill Hill, England. TSH was labeled with ${ }^{125} \mathrm{I}$ (specific activity $50-100 \mu \mathrm{Ci} / \mu \mathrm{g}$ ) by the method of Hunter and Greenwood (7), and the [ $\left.{ }^{125} \mathrm{I}\right] \mathrm{TSH}$ was purified by gel chromatography on Sephadex G-100. Duplicate serum samples of TSH standards containing an equivalent amount of suppressed serum were preincubated with the anti$\mathrm{TSH}$ for $24-48 \mathrm{~h}$ at $4^{\circ} \mathrm{C}$ before the addition of approximately $0.05 \mathrm{ng}\left[{ }^{125} \mathrm{I}\right] \mathrm{TSH}$. After a further 72 -h incubation, antibody-bound TSH was precipitated within $24 \mathrm{~h}$ by the addition of appropriate amounts of goat anti-rabbit gamma globulin. The tubes were then centrifuged, the supernates decanted, and the precipitates counted in a standard autogamma spectrometer. Less than $2 \%$ of the radioactivity was nonspecifically precipitated in tubes without anti-TSH, and greater than $80 \%$ was precipitated with excess antiTSH. The sensitivity of the method was $0.5-1.0 \mu \mathrm{U} / \mathrm{ml}$ serum. Less than $10 \%$ of normal controls had levels that were not detected.

Laboratory tests. Serum $\mathrm{T}_{4} \mathrm{D}$ was measured by a modification of the method of Murphy and Pattee (8) by the Boston Medical Laboratory, Waltham, Mass., which achieved a recovery of thyroxine from serum of approximately $95 \%(9,10)$. Serum $\mathrm{FT}_{4}$ was measured by a modification of the method of Sterling and Brenner (11).

Serum $\mathrm{T}_{8} \mathrm{D}$ was measured by a modification (12) of the method of Sterling, Bellabarba, Newman, and Brenner (13), in which the chromatographic separation of $T_{4}$ and $\mathrm{T}_{3}$ was verified by gas chromatography, showing approximately $0.5 \% \mathrm{~T}_{4}$ contamination of $\mathrm{T}_{3}$. The method of Nauman, Nauman, and Werner (14) was employed for the determination of dialyzable $\mathrm{T}_{3}\left(\% \mathrm{FT}_{3}\right)$ by Joseph Benotti at the Boston Medical Laboratory. Several modifications were employed. [ $\left.{ }^{181} \mathrm{I}\right] \mathrm{T}_{8}$ in $50 \%$ propylene glycol was obtained from Abbott Laboratories, North Chicago, Ill., with a specific activity that varied from 30 to $60 \mathrm{mCi} / \mathrm{mg}$. The $\left.{ }^{131} \mathrm{I}\right] \mathrm{T}_{3}$ was purified as follows. An aliquot of the original $\left.{ }^{131} \mathrm{I}\right] \mathrm{T}_{8}$ solution was diluted to $10 \mathrm{ml}$ with $50 \%$ propylene glycol so that $1.0 \mathrm{ml}$ contained about $100 \mu \mathrm{Ci}$ ${ }^{[131}{ }^{13} \mathrm{~T}_{3}$ and $\sim 3 \mu \mathrm{g} \mathrm{T}_{3} .1 \mathrm{ml}$ of the diluted material was added to normal serum in the ratio of $1 / 3(\mathrm{vol} / \mathrm{vol})$ and allowed to equilibrate at room temperature for $10 \mathrm{~min}$. $200 \mathrm{mg}$ of resin (Rexyn 201 Anion Exchange, Fisher Scientific Co., Pittsburgh, $\mathrm{Pa}$.) was added and the mixture was agitated with a Vortex mixer (Scientific Industries, Inc., Queens Village, N. Y.) for $30 \mathrm{~s}$ and then allowed to settle. The purified [ $\left.{ }^{131} \mathrm{I}\right] \mathrm{T}_{3}$ was removed by aspiration. Its purity was checked by paper chromatography and trichloroacetic acid precipitation and found to be $95 \%$ pure. A $0.1-\mathrm{ml}$ aliquot of the purified $\left[{ }^{131} \mathrm{I}\right] \mathrm{T}_{\mathrm{s}}$ was added to 1.2 $\mathrm{ml}$ of test serum, agitated with a Vortex mixer, and then allowed to equilibrate at room temperature for $30 \mathrm{~min}$. A $0.5 \mathrm{ml}$ aliquot of this mixture was placed in a dialysis tubing (Arthur H. Thomas Co., Philadelphia, Pa., pore diameter $48 \AA$ ) that was bent in a V shape, allowing the serum to rest in the apex of the $\mathrm{V}$. The portion of the tubing containing the serum was placed in a 24-ml Erlenmeyer flask and totally immersed in $9.0 \mathrm{ml}$ of the $0.01 \mathrm{M}$

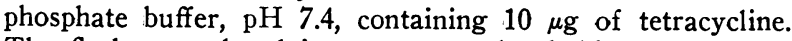
The flask was placed into a constantly shaking water bath at $37^{\circ} \mathrm{C}$ for $17 \mathrm{~h}(100$ strokes $/ \mathrm{min})$. The tubing was removed and $0.8 \mathrm{ml}$ of pooled normal serum was added to the dialyzate in the flask. The contents were mixed and allowed to stand at room temperature for $10 \mathrm{~min}$. $750 \mathrm{mg}$ Rexyn 201 anion exchange resin was added and the mixture was shaken for $2 \mathrm{~min}$ at $37^{\circ} \mathrm{C}$ at maximum shaking speed. The amount of resin-free $\left.{ }^{131} \mathrm{I}\right] \mathrm{T}_{8}$ per milliliter of dialyzate was expressed as a fraction of the $\left[{ }^{131} \mathrm{I}\right] \mathrm{T}_{\mathrm{a}}$ in $1 \mathrm{ml}$ of serum within the dialysis tubing. The percent $\mathrm{FT}_{8}$ was obtained by multiplying by 100 and appropriate dilution factors for the serum within the tubing. All serum samples were run in the same assay and in duplicate.

$\mathrm{T}_{3}$ suppression tests were performed by measuring the 24-h RAI uptake before and after the administration of $\mathrm{T}_{\mathbf{3}}, 25 \mu \mathrm{g}$ three times/day for 10 days, a normal response being a decrease in the RAI uptake of greater than $50 \%$ $(15,16)$ TSH stimulation tests were done by performing a 24-h RAI uptake and scan before and after the administration of bovine TSH (thyrotropin, Armour Pharmaceutical Co., Chicago, I1l.), $10 \mathrm{U}$ intramuscularly daily for 3 days (17).

TRH infusion. TRH stimulation tests were performed by injecting $\mathrm{TRH}$ (Abbott Laboratories) in a $200 \mu \mathrm{g}$ intravenous bolus and collecting serum samples over a 180 min period for $\mathrm{TSH}, \mathrm{T}_{4} \mathrm{D}, \mathrm{FT}_{4}$, and $\mathrm{T}_{3} \mathrm{D}(18-20)$.

TSH metabolic clearance and production rates. The metabolic clearance and production rates of $\mathrm{TSH}$ were determined by a constant infusion-to-equilibrium method $(21,22)$ recently applied to other polypeptide $(23-25)$ and glycoprotein hormones $(26,27)$. In this method ${ }^{8}$ highly purified human TSH was labeled with ${ }^{131} \mathrm{I}$ (7) to a specific activity of $\sim 50 \mu \mathrm{Ci} / \mu \mathrm{g}$ and separated over a G-100 Sephadex column. After infusion into patients and collection of serum samples at equilibrium, the $\left[{ }^{131} \mathrm{I}\right] \mathrm{TSH}$ was separated by addition of excess rabbit anti-human TSH and precipitated after a 24-h incubation with goat anti-rabbit gamma globulin. The precipitates were counted in a standard autogamma spectrometer, and metabolic clearance rate (MCR) was determined by the formula:

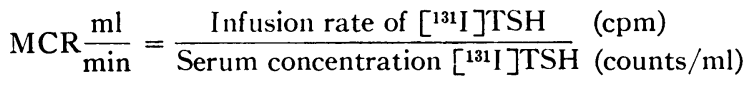

The endogenous production rate of TSH was then calculated by multiplying the MCR times the endogenous serum concentration of TSH. The mean normal MCR of TSH for this laboratory is $\sim 50 \mathrm{ml} / \mathrm{min}$ with a range from 30 to $85 \mathrm{ml} / \mathrm{min}$, which is similar to that found by Odell, Utiger, Wilber, and Condliffe (28), who utilized a singleinjection method and determined the mean metabolic clearance rates in euthyroid subjects to be $42.5 \mathrm{ml} / \mathrm{min}$ with a range from 19.2 to $87 \mathrm{ml} / \mathrm{min}$. The mean normal TSH production rate for this laboratory is $\sim 75 \mathrm{mU} /$ day with a range from $<25$ to $150 \mathrm{mU} /$ day as compared to the normal mean cited by Odell et al. of $165.2 \mathrm{mU} /$ day (28).

${ }^{3}$ Ridgway, E. C., B. D. Weintraub, and F. Maloof. 1974. Metabolic clearance and production rates of human thyrotropin. J. Clin. Invest. In press. 


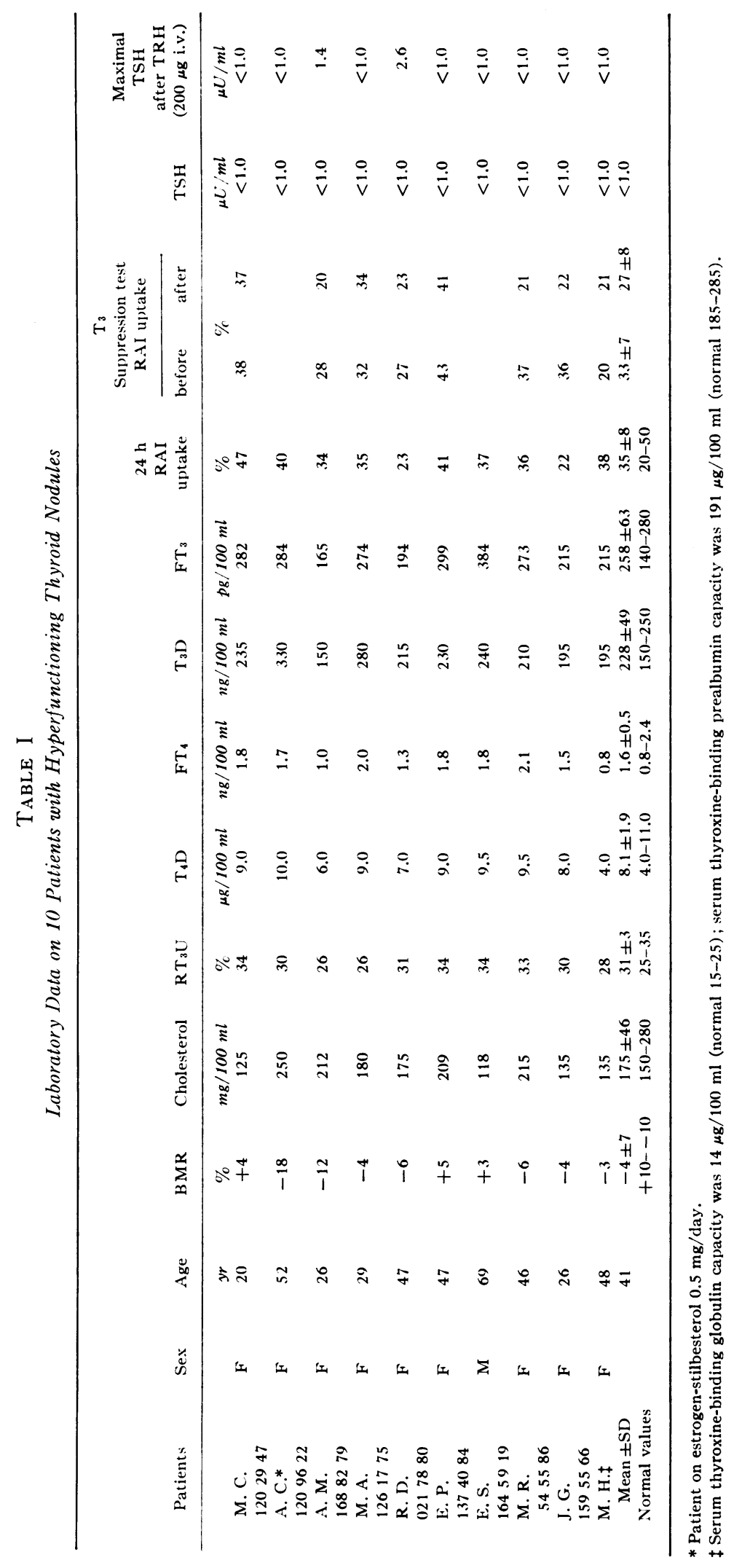




\section{RESULTS}

Patients. The patients with hyperfunctioning thyroid nodules included nine women and one man with ages ranging from 20 to 69 (Table I). All patients had normal values for $\mathrm{T}_{4} \mathrm{D}, \mathrm{FT}_{4}, \mathrm{RAI}$ uptake, $\mathrm{BMR}$, and $\mathrm{T}_{8}$ resin uptake.

The mean $T_{3} D$ for the 10 patients with hyperfunctioning thyroid nodules was $228 \pm 50 \mathrm{ng} / 100 \mathrm{ml}$ (SD). 2 of the 10 patients had slightly elevated levels; one of these two patients, A. C., was taking stilbesterol at the time of study. The normal range for $T_{3} \mathrm{D}$ for about $1,000 \mathrm{pa}-$ tients in this laboratory has been $150-250 \mathrm{ng} / 100 \mathrm{ml}$; however, the $T_{3} D$ ranged from 140 to $215 \mathrm{ng} / 100 \mathrm{ml}$ in the twelve normal patients used in this study to determine $\% \mathrm{FT}_{3}$. The mean $\% \mathrm{FT}_{3}$ concentration was $0.11 \%$ (range 0.086-0.16) with the normal mean for 12 control patients being $0.12 \%$ (range $0.095-0.16$, Table II). The mean calculated $\mathrm{FT}_{\mathbf{3}}$ concentration was $258 \mathrm{pg} / 100 \mathrm{ml}$ (range 165-384 pg/100 ml) with the normal mean for 12 control patients being $211 \mathrm{pg} / 100 \mathrm{ml}$ (range 140-247 $\mathrm{pg} / 100 \mathrm{ml}$ ). Although 4 of the 10 patients had values for $\mathrm{FT}_{3}$ that were above two standard deviations of the mean for the control group, there was no statistically significant difference between the mean $\% \mathrm{FT}_{3}$ or $\mathrm{FT}_{3}$ of the patients with hyperfunctioning thyroid nodules and the 12 control patients. Patients with hyperthyroidism had a mean $\% \mathrm{FT}_{3}$ of $0.15 \%$ (range $0.09-0.27 \%$ ) and a mean $\mathrm{FT}_{3}$ of $827 \mathrm{pg} / 100 \mathrm{ml}$ (range $282-3,350 \mathrm{pg} / 100 \mathrm{ml}$ ).

$T_{s}$ suppression and TSH stimulation tests. Ts suppression tests done on eight patients were abnormal since the mean RAI uptake decreased only from 33 to $27 \%$. Thyroid scans were done on all patients initially and showed a homogenous uptake exclusively in the hyperfunctioning nodule with failure to incorporate RAI in the extranodular tissue. TSH stimulation tests were done on 9 of the 10 patients, demonstrating an increased incorporation of RAI by the extranodular tissue.

Basal serum TSH. The mean serum TSH level in the fasting and basal state for the 56 control subjects was $1.63 \pm 0.79 \mu \mathrm{U} / \mathrm{ml}(\mathrm{SD})$; the mean serum TSH level for the 11 control subjects studied in detail was $1.67 \pm$

TABLE II

$F_{3}$ Concentration in the Serum of Normal Patients and those with Various Thyroid Disorders

\begin{tabular}{lrccc}
\hline & $n$ & $\mathrm{~T}_{3} \mathrm{D} \pm \mathrm{SD}$ & $\% \mathrm{FT}_{3} \pm \mathrm{SD}$ & $\mathrm{FT}_{3} \pm \mathrm{SD}$ \\
\hline & & $n g / 100 \mathrm{ml}$ & $\%$ & $p g / 100 \mathrm{ml}$ \\
Normals & 12 & $178 \pm 30$ & $0.12 \pm 0.02$ & $211 \pm 34$ \\
Hot nodules & 10 & $228 \pm 50$ & $0.11 \pm 0.02$ & $258 \pm 63$ \\
$\begin{array}{l}\text { Hyperthyroid } \\
\text { Hypothyroid }\end{array}$ & 9 & $\mathbf{4 8 4} \pm 352$ & $0.15 \pm 0.04$ & $\mathbf{8 2 7} \pm 912$ \\
$\begin{array}{l}\text { Euthyroid after } \\
\text { treatment of } \\
\text { hyperthyroidism }\end{array}$ & $\mathbf{8}$ & $\mathbf{9 1 \pm 4 5}$ & $\mathbf{0 . 1 1} \pm \mathbf{0 . 0 1}$ & $100 \pm 51$ \\
\hline
\end{tabular}

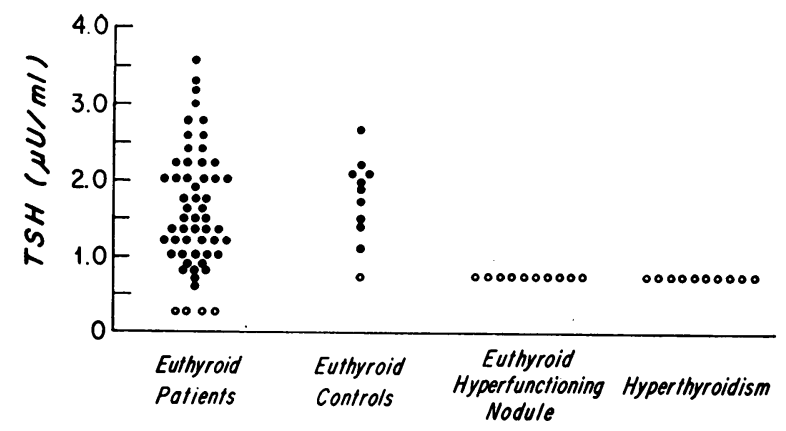

Figure 1 Basal serum TSH concentration in euthyroid patients (56), euthyroid controls (11), and patients with hyperfunctioning thyroid nodules (10) or hyperthyroidism (10). Open circle, 0 , denotes an undetectable $(<0.5-1.0$ $\mu \mathrm{U} / \mathrm{ml}$ ) $\mathrm{TSH}$ concentration.

$0.68 \mu \mathrm{U} / \mathrm{ml}$ (SD), with 1 of the 11 subjects having an undetectable serum TSH concentration. In the patients with hyperfunctioning thyroid nodules, the basal serum TSH levels were not detected and not distinguished from those of hyperthyroid patients (Fig. 1). Serum TSH levels in the four hypothyroid patients were elevated in each case before therapy (Table III).

TRH stimulation tests. In 11 control subjects, the mean maximal TSH level after TRH stimulation was $11.9 \pm 3.2 \mu \mathrm{U} / \mathrm{ml}(\mathrm{SD})$ at $30 \mathrm{~min}$ (Fig. 2). Hyperthyroid patients failed to release TSH in response to TRH stimulation. In the group of patients with hyperfunctioning thyroid nodules, 8 of 10 failed to release TSH. 2 of the 10 patients had minimal responses to TRH stimulation that were well below the range of normal.

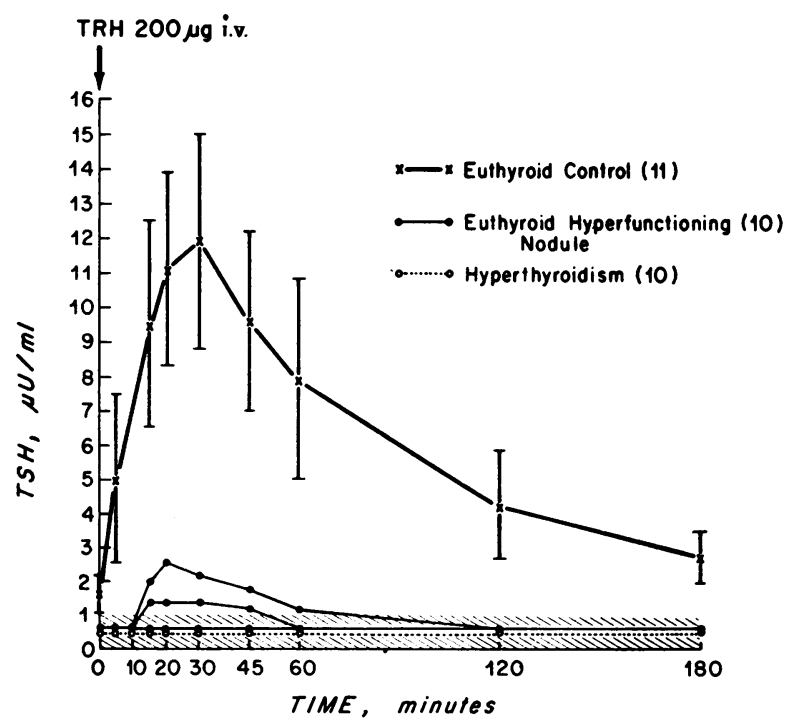

Figure 2 Serum TSH response to TRH stimulation. Euthyroid controls $\times \longrightarrow \times$, hyperfunctioning thyroid nodule $\bullet-$, hyperthyroidism $\mathrm{O}-\mathrm{O}$. 
TABLE III

TSH Response to TRH in Four Hypothyroid Patients Given Increasing Doses of L-Thyroxine and Sequential TRH Stimulation Tests

\begin{tabular}{|c|c|c|c|c|c|c|c|c|}
\hline Patient & $\begin{array}{c}\text { Date of TRH } \\
(200 \mu \mathrm{g} \text { i.v. }) \\
\text { stimulation } \\
\end{array}$ & $\begin{array}{c}\text { L-thyroxine } \\
\text { dosage }\end{array}$ & $\begin{array}{c}\text { Basal } \\
\text { TSH } \\
\end{array}$ & $\begin{array}{c}\text { Maximal } \\
\text { TSH after } \\
\text { TRH }\end{array}$ & $\mathrm{T}, \mathrm{D}$ & $\mathrm{FT}_{4}$ & $\mathrm{~T}_{3} \mathrm{D}$ & $\begin{array}{c}\text { 24-h RAI } \\
\text { uptake }\end{array}$ \\
\hline M. S. & $2 / 12 / 72$ & $\begin{array}{r}\mu g \\
0\end{array}$ & $\begin{array}{c}\mu U / m l \\
84\end{array}$ & $\begin{array}{l}\mu U / m l \\
203\end{array}$ & $\begin{array}{c}\mu \mathrm{g} / 100 \mathrm{ml} \\
2.5\end{array}$ & $\begin{array}{c}n g / 100 \mathrm{ml} \\
0.4\end{array}$ & $\begin{array}{c}n g / 100 m l \\
95\end{array}$ & $\begin{array}{l}\% \\
31\end{array}$ \\
\hline \multirow[t]{5}{*}{ MGH No. 1540329} & $3 / 16 / 72$ & 50 & 46 & 180 & 4.5 & 1.0 & 140 & 13 \\
\hline & $4 / 14 / 72$ & 100 & 9 & 72 & 6.5 & 1.1 & 110 & 6 \\
\hline & $5 / 12 / 72$ & 150 & 7 & 45 & 7.0 & 1.2 & 150 & 5 \\
\hline & $6 / 9 / 72$ & 200 & $<0.5$ & 3 & 7.5 & 1.4 & 170 & $<1$ \\
\hline & $7 / 7 / 72$ & 300 & $<0.5$ & $<0.5$ & 10.5 & 2.4 & 290 & $<1$ \\
\hline M. Q. & $8 / 7 / 71$ & 0 & 35 & 102 & 2.5 & 0.4 & 80 & 36 \\
\hline \multirow[t]{4}{*}{ MGH No. 1200345} & $8 / 25 / 71$ & 100 & 8 & 36 & 6.5 & 1.2 & 110 & 9 \\
\hline & $9 / 16 / 71$ & 150 & $<0.5$ & 5 & 8.5 & 1.9 & 190 & $<1$ \\
\hline & $10 / 22 / 71$ & 200 & $<0.5$ & $<0.5$ & 9.5 & 2.4 & 160 & $<1$ \\
\hline & $12 / 3 / 71$ & 300 & $<0.5$ & $<0.5$ & 11.5 & 2.3 & 240 & $<1$ \\
\hline L. L. & $5 / 31 / 71$ & 0 & 18 & 115 & 3.0 & 0.5 & 150 & 18 \\
\hline \multirow[t]{6}{*}{ MGH No. 1222053} & $6 / 26 / 71$ & 0 & 10 & 88 & 4.5 & 0.7 & 115 & \\
\hline & $8 / 21 / 71$ & 100 & 4 & 31 & 7.0 & 1.3 & 125 & 5 \\
\hline & $9 / 18 / 71$ & 150 & 4 & 48 & 6.5 & 1.2 & 175 & 10 \\
\hline & $10 / 9 / 71$ & 200 & $<0.5$ & 4 & 9.5 & 2.5 & 200 & $<1$ \\
\hline & $11 / 6 / 71$ & 300 & $<0.5$ & $<0.5$ & 11.0 & 2.3 & 255 & $<1$ \\
\hline & $12 / 4 / 71^{*}$ & 300 & $<0.5$ & $<0.5$ & 9.0 & 1.7 & 190 & $<1$ \\
\hline J. S. & $7 / 24 / 71$ & 0 & 6 & 85 & 3.0 & 0.7 & 155 & 35 \\
\hline \multirow[t]{4}{*}{ MGH No. 1087269} & $8 / 10 / 71$ & 100 & $<0.5$ & 11 & 7.0 & 1.5 & 150 & 9 \\
\hline & $8 / 31 / 71$ & 150 & $<0.5$ & $<0.5$ & 9.0 & 1.7 & 245 & $<1$ \\
\hline & $9 / 21 / 71$ & 200 & $<0.5$ & $<0.5$ & 9.0 & 2.2 & 180 & $<1$ \\
\hline & $10 / 19 / 71$ & 300 & $<0.5$ & $<0.5$ & 12.5 & 2.5 & 360 & $<1$ \\
\hline Euthyroid controls & & None & 1.67 & 11.9 & 6.2 & 1.4 & & 24 \\
\hline
\end{tabular}

* TRH $-1.0 \mathrm{mg}$ used for this study.

The data on the four hypothyroid patients are presented in Table III. Serial TRH stimulation tests given at intervals of 3-4 wk on increasing doses of oral L-thyroxine were correlated with RAI uptake and circulating levels of $\mathrm{T}_{4} \mathrm{D}, \mathrm{FT}_{4}$ and $\mathrm{T}_{3} \mathrm{D}$. In each case the TSH response to TRH was blunted at a time when the circulating levels of $\mathrm{T}_{4} \mathrm{D}, \mathrm{FT}_{4}$, and $\mathrm{T}_{3} \mathrm{D}$ were within the normal range: $\mathrm{T}_{4} \mathrm{D}, 7.5-9.5 \mu \mathrm{g} / 100 \mathrm{ml}$; FT, $1.4-2.5 \mathrm{ng} / 100$ $\mathrm{ml}$, and $\mathrm{T}_{3} \mathrm{D}, 170-245 \mathrm{ng} / 100 \mathrm{ml}$. Each patient appeared to have complete inhibition of TRH stimulation after the administration of L-thyroxine that varied from 150 to $300 \mu \mathrm{g}$ daily. Patient L. L. was completely suppressed on $300 \mu \mathrm{g}$ of L-thyroxine and failed to respond to either 200 or $1,000 \mu \mathrm{g}$ of TRH given intravenously. The completely suppressed TSH response to $\mathrm{TRH}$ was associated with an RAI of less than $1 \%$.

$T S H$ metabolic clearance and production rates. Only one patient (J.G.) was available for serial studies before and after partial thyroidectomy. Preoperatively the patient had an undetectable TSH concentration and no re- sponse to TRH stimulation (Fig. 3), a TSH MCR of $40 \mathrm{ml} / \mathrm{min}$ and an undetectable $\mathrm{TSH}$ production rate of $<29 \mathrm{mU} /$ day (Table IV). After the operation, the circulating $\mathrm{T}_{4} \mathrm{D}, \mathrm{FT}_{4}$, and $\mathrm{T}_{3} \mathrm{D}$ dropped to low normal levels by the 4th day. Subsequently, the serum TSH rose to elevated levels of $(10 \mu \mathrm{U} / \mathrm{ml})$ during the 2 nd postoperative wk (Fig. 4) and then dropped to a normal level as the $T_{4} \mathrm{D}, \mathrm{FT}_{4}$, and $\mathrm{T}_{3} \mathrm{D}$ rose to nearly preoperative levels. 1 mo after the operation, the patient had a normal serum $\mathrm{TSH}$ concentration of $1.7 \mu \mathrm{U} / \mathrm{ml}$ and a positive response to $\mathrm{TRH}$ stimulation (Fig. 5). At this time the TSH MCR was unchanged at $42 \mathrm{ml} / \mathrm{min}$, but the TSH production rate was $103 \mathrm{mU} /$ day (Table IV).

\section{DISCUSSION}

In 1947 Cope, Rawson, and McArthur (1) demonstrated that hyperfunctioning thyroid nodules in hyperthyroid patients were associated with anatomical atrophy and physiological inactivation of the extranodular tissue. Dobyns and Lennon (29) confirmed the physiological 


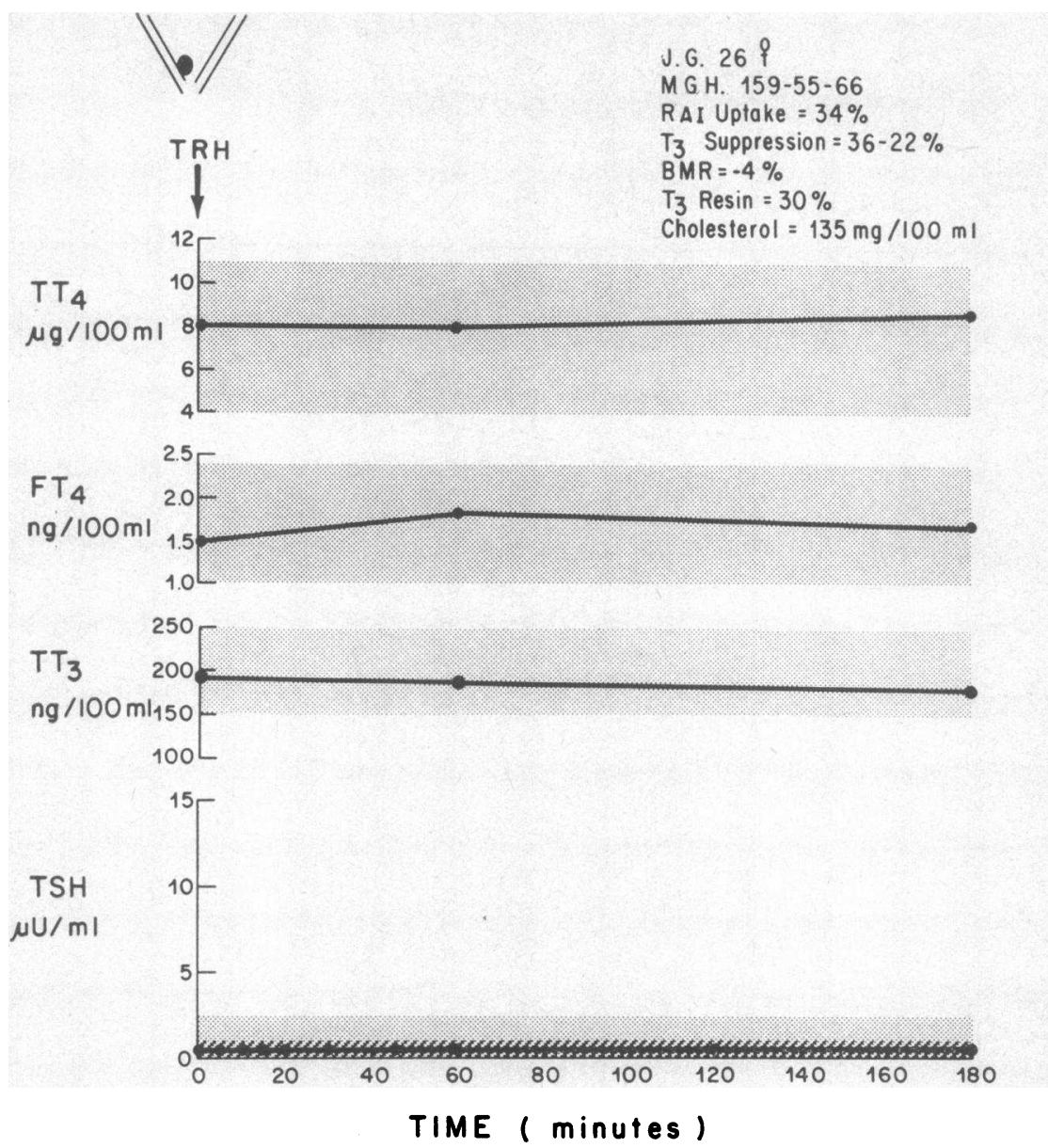

Figure 3 Preoperative TSH response to TRH stimulation in patient J. G. Stippled area denotes normal range; slashed area denotes undètectable range of serum $\mathrm{TSH}$ concentration. Thyroid scan in upper left corner denotes radioactivity in the single nodule on right.

inactivation of the extranodular tissue by radioautography demonstrating that the extranodular tissue concentrated much less ${ }^{131} \mathrm{I}$ than the hyperfunctioning nodule, regardless of whether the patient was clinically hyperthyroid or euthyroid. Subsequently, Sheline and McCormack (2) reported that the administration of bovine $\mathrm{TSH}$ to patients with hyperfunctioning thyroid nodules led to the incorporation of RAI in the extranodular tis- sue. The latter effect was also noted by Green and Ingbar (3) after removal of the hyperfunctioning thyroid nodule. These observations gave strong support for the assumption that anatomical and physiological inactivation of the extranodular tissue was a direct result of suppressed endogenous TSH secretion.

The present study, utilizing a sensitive radioimmunoassay that distinguished low from normal levels of se-

TABLE IV

Effect of Partial Thyroidectomy on Circulating Levels of Thyroid Hormones, TSH Concentration, TSH Response to TRH, TSH Metabolic Clearance, and Production Rates

\begin{tabular}{|c|c|c|c|c|c|c|c|}
\hline & $T_{4} D$ & $\mathrm{FT}_{4}$ & $\mathrm{~T}_{3} \mathrm{D}$ & Basal TSH & $\begin{array}{l}\text { Maximal TSH } \\
\text { after TRH }\end{array}$ & $\begin{array}{l}\text { TSH } \\
\text { MCR }\end{array}$ & $\begin{array}{l}\text { TSH } \\
\text { PR* }\end{array}$ \\
\hline & $\mu \mathrm{g} / 100 \mathrm{ml}$ & $\mathrm{ng} / 100 \mathrm{ml}$ & $\mathrm{ng} / 100 \mathrm{ml}$ & $\mu U / m l$ & $\mu U / m l$ & $\mathrm{ml} / \min$ & $m U / d a y$ \\
\hline Before & 8.0 & 1.5 & 195 & $<0.5$ & $<0.5$ & 40 & $<29$ \\
\hline After & 7.5 & 1.4 & 155 & 1.7 & 24 & 42 & 103 \\
\hline
\end{tabular}

* $\mathrm{PR}$, production rate. 


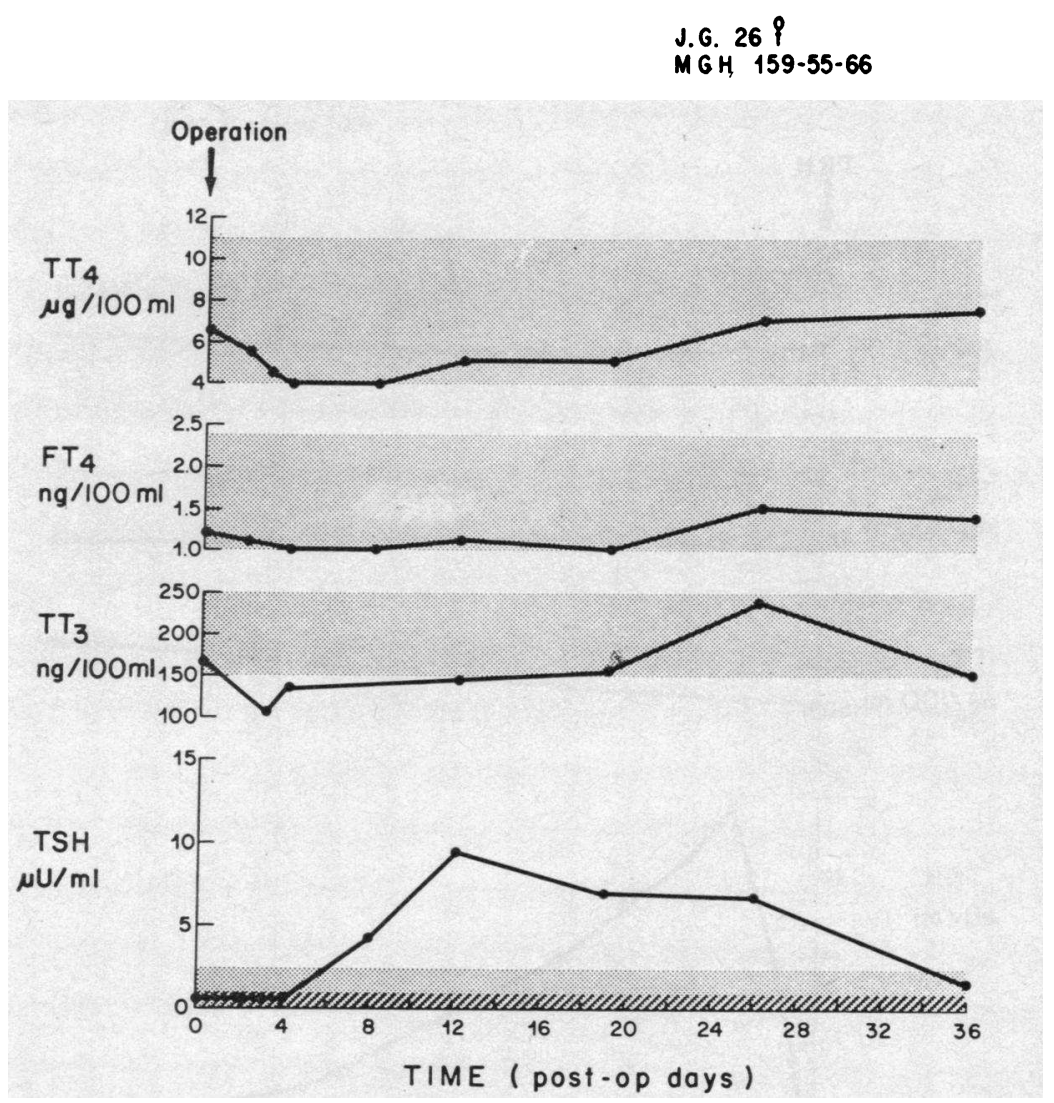

FIgURE 4 Postoperative course of patient J. G., correlating decreasing $T_{4} D, F T_{4}$, and $T_{3} D$ with increasing serum TSH concentration. Stippled area denotes normal range; slashed area denotes undetectable range of serum TSH concentration.

rum $\mathrm{TSH}$, demonstrated that all patients with hyperfunctioning thyroid nodules had undetectable basal concentrations of serum TSH. These undetectable concentrations of serum TSH were not distinguished from those of patients with classical hyperthyroidism but did differ from those of control patients who had a mean serum TSH of $1.67 \pm 0.68 \mu \mathrm{U} / \mathrm{ml}$.

Stimulation of the pituitary thyrotropin cells by TRH revealed evidence consistent with suppression of the thyrotropin cells. In 8 of 10 patients with hyperfunctioning thyroid nodules, TRH failed to release TSH, data not distinguished from those seen in patients hyperthyroid secondary to Graves' disease $(30,31)$, toxic adenoma (32), or even in patients with euthyroid Graves' disease (33). Two of the study patients released minimal amounts of TSH after the TRH challenge.

Serial studies in one patient, J. G., before removal of the thyroid nodule showed that an undetectable basal

' Cooper, D., E. C. Ridgway, L. Lorenz, and F. Maloof. 1972. The thyroid-pituitary-hypothalamic axis in euthyroid patients with Graves' ophthalmopathy. Clin. Res. 20: 864. (Abstr.) serum TSH concentration and an absent TSH response after TRH stimulation were due to an undetectable TSH production rate. After removal of the nodule, a normal serum $\mathrm{TSH}$ concentration was associated with a normal TSH production rate and a positive $\mathrm{TSH}$ response to $\mathrm{TRH}$ stimulation without alterations in the metabolic clearance of the hormone. In addition, comparison of the pre- and postoperative T.D (8.0 vs. $7.5 \mu \mathrm{g} / 100 \mathrm{ml}), \mathrm{FT}_{4}$ (1.5 vs. $1.4 \mathrm{ng} / 100 \mathrm{ml}$ ), and $\mathrm{T}_{\mathrm{8}} \mathrm{D}$ (195 vs. $155 \mathrm{ng} / 100$ $\mathrm{ml})$ concentrations suggests, that relatively small changes in the circulating thyroid hormones can produce significant alterations in TSH secretion.

In spite of the normal concentration of circulating thyroid hormones in a majority of these patients with hyperfunctioning thyroid nodules, basal concentrations of TSH were undetectable, and serum TSH failed to rise normally after TRH stimulation. Several possibilities for the suppression of pituitary $\mathrm{TSH}$ secretion have been entertained. First, the nodules may have produced an unidentified substance capable of suppressing pituitary TSH secretion, an hypothesis lacking experimental evidence. Second, $\mathrm{FT}_{3}$ concentrations were measured in pa- 


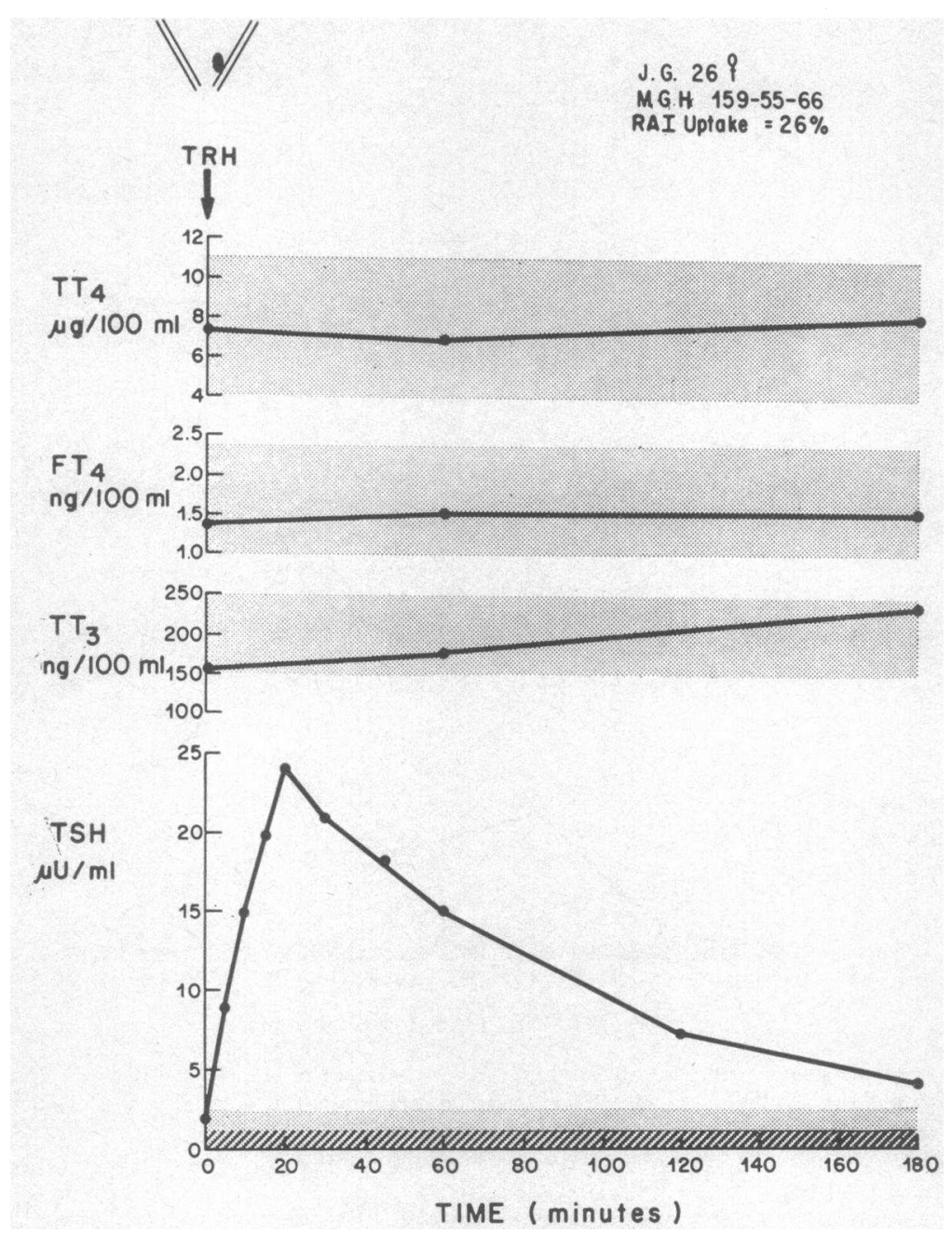

Figure 5 Postoperative TSH response to TRH stimulation in patient J. G. Stippled area denotes normal range; slashed area denotes undetectable range of serum TSH concentration. Thyroid scan in upper left corner denotes radioactivity in paranodular tissue on left.

tients with various thyroid disorders (Table II). The dialyzable fraction of $\mathrm{T}_{3}$ for normal controls $(0.12 \pm$ $0.02 \%$ ) in our studies is considerably lower than those previously reported by Nauman et al. (14) for normals $(0.46 \pm 0.14 \%)$ and slightly lower than those $(0.28 \%)$ reported by Woeber, Hecker, and Ingbar (34). This probably stems from the variations and modification in the techniques of the assay. Purification of the labeled test substance $(35,36)$ and careful attention to the ionic strength and $\mathrm{pH}$ of the buffer and temperature (37) have led to a decrease over the years in the reported normal values of dialyzable $\mathrm{T}_{4}$ from about $0.05 \%$ (11, 38,39 ) to about $0.020 \%$ (37), which is the value for the percent FT, used in our studies. Although our percent $\mathrm{FT}_{8}$ is lower than the values reported by other investigators, the alterations in the dialyzable fraction in our patients with various thyroid disorders (Table II) were similar to those reported by Nauman et al. (14). Our data reveal that there is an increase in the dialyzable $\mathrm{T}_{3}$ fraction in patients with hyperthyroidism but there was no increase in the patients with hyperfunctioning thyroid nodules when compared with controls. This is not surprising, since there were no apparent binding abnormalities in our patients and the $T_{4} \mathrm{D}$ concentrations were normal. It appears that a significant increase in the serum thyroxine is required to increase significantly the dialyzable fraction of $T_{3}(34)$. Hence, an increase in the dialyzable $T_{3}$ fraction is not an explanation for our findings of suppression of TSH secretion. Third, serum TSH concentration and pituitary $\mathrm{TSH}$ reserve may be more closely correlated with the production or disposal rates of $T_{4}$ and $T_{3}$ and not directly with their serum concentrations. Although production and disposal rates of $T_{4}$ and $T_{3}$ were not measured, one might postulate slightly 
increased values. Fourth, although the serum concentrations of thyroid hormones found in these patients were within the normal range for the general population; they were excessive for these individual patients. Excessive thyroid hormone concentration usually produces signs of thyrotoxicosis but in these patients there were none of the usual signs or symptoms of thyrotoxicosis. Thus, the thyroid hormone concentrations may have been excessive enough to inhibit pituitary $\mathrm{TSH}$ secretion without producing clinical thyrotoxicosis.

The phenomena of pituitary suppression of TSH secretion in the presence of normal circulating concentrations of thyroid hormones were also documented in the four hypothyroid patients by the chronic administration of increasing doses of L-thyroxine. Each hypothyroid patient appeared to achieve suppression of pituitary $\mathrm{TSH}$ secretion after the administration of varying doses of L-thyroxine that led to a variable but normal level of $\mathrm{T}_{4} \mathrm{D}, \mathrm{FT}_{4}$, and $\mathrm{T}_{3} \mathrm{D}$. In addition, the $\mathrm{TSH}$ response to $\mathrm{TRH}$ stimulation was altered from partial to complete suppression in each hypothyroid patient after relatively small changes in the serum concentration of $T_{4} D, F T_{4}$, and $T_{3} D$. These data are consistent with those of Snyder and Utiger (40) who have demonstrated the extreme sensitivity of the TRH-induced TSH release to inhibition in normal and hypothyroid subjects after the chronic oral administration of quantities of $T_{4}$ and $T_{3}$ that did not raise serum $T_{4} D$ and $T_{3}$ (RIA) above the normal range. The sensitivity of the TRH-induced TSH release to inhibition by single doses $(50-100 \mu \mathrm{g})$ of $\mathrm{T}_{3}$ has also been reported $(41,42)$. Thus it is evident that there is a very sensitive feedback control between the concentrations of circulating thyroid hormones and that of the secretion of TSH. Feedback inhibition by thyroid hormones may occur at different serum concentration of $T_{4}$ and $T_{3}$ in different patients and may occur with only minimal changes in the serum concentrations of $T_{4}$ and $T_{3}$ in any one patient.

In summary, these studies in 10 patients with hyperfunctioning thyroid nodules documented pituitary-thyrotropin-cell suppression on the basis of undetectable basal TSH concentrations, normal metabolic clearance of $\mathrm{TSH}$, an undetectable production rate of $\mathrm{TSH}$, and a failure of the pituitary to release TSH after TRH stimulation. Although the patients were judged to be euthyroid on clinical grounds, it appears that these patients are secreting an amount of thyroid hormone that is excessive for their pituitaries. Furthermore, these patients appear to exhibit a certain tolerance to slight increases in the serum concentration of thyroid hormone, since they fail to develop overt clinical evidence of hyperthyroidism.

\section{ACKNOWLEDGMENTS}

The authors wish to thank Dr. Michael Anderson and the Abbott Drug Company for provisions of the TRH. In addition we are indebted to Miss Ruth King and Mrs. Rose Rich for expert secretarial help.

This investigation was supported in part by U.S.P.H.S. Grants RO1 HD-05195, Metabolic Research Grant AM04501, Endocrine Training Grant AM-05205, and American Cancer Grant 1399-C-1.

\section{REFERENCES}

1. Cope, O., R. W. Rawson, and J. W. McArthur. 1947. The hyperfunctioning single adenoma of the thyroid. Surg. Gynecol. Obst. 84: 415.

2. Sheline, G. E., and K. McCormack. 1960. Solitary hyperfunctioning thyroid nodules. J. Clin. Endocrinol. Metab. 20: 1401 .

3. Green, W. L., and S. H. Ingbar. 1962. The effect of iodide on the rate of release of ${ }^{131} \mathrm{I}$ from autonomous thyroid nodules. J. Clin. Invest. 41: 173.

4. Solomon, D. H., J. Benotti, L. J. DeGroot, M. A. Greer, V. J. Pileggi, J. A. Pittman, J. Robbins, H. A. Selenkow, K. Sterling, and R. Volpe. 1972. A nomenclature for tests of thyroid hormones in serum; report of a committee of The American Thyroid Association. J. Clin. Endocrinol. Metab. 34: 884.

5. Odell, W. D., J. F. Wilber, and R. D. Utiger. 1967. Studies of thyrotropin physiology by means of radioimmunoassay. Recent Prog. Horm. Res. 23: 47.

6. Patel, Y. C., H. G. Burger, and B. Hudson. 1971. Radioimmunoassay of serum thyrotropin: sensitivity and specificity. J. Clin. Endocrinol. Metcb. 33: 768.

7. Hunter, W. M., and F. C. Greenwood. 1962. Preparation of iodine- ${ }^{131}$ labeled human growth hormone of high specific activity. Nature (Lond.). 194: 495.

8. Murphy, B. E. P., and C. J. Pattee. 1964. Determination of thyroxine utilizing the property of protein binding. J. Clin. Endocrinol. Metab. 24: 187.

9. Cassidy, C. F., J. Benotti, and S. C. Pino. 1968. Clinical evaluation of the determination of thyroxine iodide. $J$. Clin. Endocrinol. Metab. 28: 420.

10. Benotti, J., and S. C. Pino. 1972. Assay of serum thyroxine. Total thyroxine by competitive protein binding (displacement). Stand. Methods Clin. Chem. 7: 255.

11. Sterling, K., and M. A. Brenner. 1966. Free thyroxine in human serum: simplified measurement with the aid of magnesium precipitation. J. Clin. Invest. 45: 153.

12. Benotti, J., R. Grimaldi, S. C. Pino, and F. Maloof. 1971. A modified method for total triiodothyronine $\left(\mathrm{T}_{3}\right)$ by competitive protein binding. In Further Advances in Thyroid Research: K. Fellinger and R. Hofer, editors. Verlag der Wiener Medizinischen Akademie, Vienna 2: 1121 .

13. Sterling, K. D, D. Bellabarba, E. S. Newman, and M. A. Brenner. 1969. Determination of triiodothyronine concentration in human serum. J. Clin. Invest. 48: 1150.

14. Nauman, J. A., A. Nauman, and S. C. Werner. 1967. Total and free triiodothyronine in human serum. $J$. Clin. Invest. 46: 1346.

15. Werner, S. C., and M. Spooner. 1955. A new and simple test for hyperthyroidism employing L-triiodothyronine and the twenty-four hour I-131 uptake method. Bull. N. Y. Acad. Med. 31: 137.

16. Burke, G. 1967. The triiodothyronine suppression test. Am.J.Med. 42: 600 . 
17. Fore, W., and J. Wynn. 1966. The thyrotropin stimulation test. Am. J. Med. 40: 90.

18. Bowers, C. Y., A. V. Schally, A. S. Schalch, C. Gual, A. J. Kastin, and K. Folkers. 1970. Activity and specificity of synthetic thyrotropin-releasing hormone in man. Biochem. Biophys. Res. Commun. 39: 352.

19. Hershman, J. M., and J. A. Pittman, Jr. 1970. Response to synthetic thyrotropin-releasing hormone in man. $J$. Clin. Endocrinol. Metab. $31: 457$.

20. Anderson, M. S., C. Y. Bowers, A. J. Kastin, A. S. Schalch, A. V. Schally, P. J. Snyder, R. D. Utiger, J. F. Wilber, and A. J. Wise. 1971. Synthetic thyrotropinreleasing hormone. N. Engl. J. Med. 285: 1279.

21. Tait, J. F. 1963. Review: the use of isotopic steroid for the measurement of production rates in vivo. J. Clin. Endocrinol. Metab. 23: 1285.

22. Tait, J. F., and S. Burstein. 1964. In vivo studies of steroid dynamics in man. Hormones. 5: 441.

23. Taylor, A. L., J. L. Finster, and D. H. Mintz. 1969. Metabolic clearance and production rates of human growth hormone. J. Clin. Invest. 48: 2349.

24. MacGillivray, M. H., L. A. Frohman, and J. Doe. 1970. Metabolic clearance and production rates of human growth hormone in subjects with normal and abnormal growth. J. Clin. Endocrinol. Metab. 30: 632.

25. Cameron, D. P., H. G. Burger, K. J. Catt, and A. Doig. 1969. Metabolic clearance rate of radioiodinated human growth hormone in man. J. Clin. Invest. 48: 1600.

26. Kohler, P. O., G. T. Ross, and W. D. Odell. 1968. Metabolic clearance and production rates of human luteinizing hormone in pre and postmenopausal women. J. Clin. Invest. $47: 38$.

27. Coble, Y. D., P. O. Kohler, C. M. Cargille, and G. T. Ross. 1969. Production rates and metabolic clearance rates of human follicle-stimulating hormone in premenopausal and postmenopausal women. J. Clin. Invest. 48: 359.

28. Odell, W. D., R. D. Utiger, J. F. Wilber, and P. G. Condliffe. 1967. Estimation of the secretion rate of thyrotropin in man. J. Clin. Invest. 46: 953.

29. Dobyns, B. M., and B. Lennon. 1948. A study of the histopathology and physiologic function of thyroid tumors, using radioactive iodine and radioautography. $J$. Clin. Endocrinol. Metab. 8: 732.

30. Ormston, B. J., R. J. Cryer, R. Gorry, G. M. Besser, and $\mathrm{R}$. Hall. 197.1. Thyrotropin-releasing hormone as a thyroid-function test. Lancet. 2: 10.

31. Hershman, J. M., and J. A. Pittman. 1971. Utility of the radio-immunoassay of serum thyrotropin in man. Ann. Intern. Med. 74 : 481.
32. Mornex, R., C. Z. Bizollon, R. Fitoussi, J. C. Gagnaire, and D. Peynaud. 1971. Exploration des insuffisances antehypophysaires par l'hormone liberant T.S.H. (TRH). Ann. Endocrinol. $32: 823$.

33. Lawton, N. F., R. P. Ekins, and J. D. N. Nabarro. 1971. Failure of pituitary response to thyrotropinreleasing hormone in euthyroid Graves' disease. Lancet. 2: 14 .

34. Woeber, K. A., E. Hecker, and S. H. Ingbar. 1970. The effects of an acute load of thyroxine on the transport and peripheral metabolism of triiodothyronine in man. J. Clin. Invest. 49: 650.

35. Schussler, G. C., and J. E. Plager. 1967. Effect of preliminary purification of ${ }^{131} \mathrm{I}$-thyroxine on the determination of free thyroxine in serum. J. Clin. Endocrinol. Metab. 27: 242.

36. Volpert, E. M., M. Martinez, and J. H. Oppenheimer. 1967. Radioiodinated impurities in commercial preparations of $\left.{ }^{131} I\right]$ thyroxine and their effect on the measurement of free thyroxine in human serum by equilibrium dialysis. J. Clin. Endocrinol. Metab. 27: 421.

37. Spaulding, S. W., and R. I. Gregerman. 1972. Free thyroxine in serum by equilibrium dialysis: effects of dilution, specific ions and inhibitors of binding. J. Clin. Endocrinol. Metab. 34 : 974.

38. Oppenheimer, J. H., R. Squef, M. I. Surks, and H. Hauer. 1963. Binding of thyroxine by serum proteins evaluated by equilibrium dialysis and electrophoresis techniques. Alterations in nonthyroidal illness. J. Clin. Invest. 42 : 1769.

39. Ingbar, S. H., L. E. Braverman, N. A. Dawber, and G. Y. Lee. 1965. A new method for measuring the free thyroid hormone in human serum and an analysis of the factors that influence its concentration. J. Clin. Invest. 44 : 1679.

40. Snyder, P. J., and R. D. Utiger. 1972. Inhibition of thyrotropin response to thyrotropin-releasing hormone by small quantities of thyroid hormones. J. Clin. Invest. $51: 2077$.

41. Bowers, C. Y., A. V. Schally, A. Kastin, A. Arimura, D. S. Schalch, C. Gual, E. Castineda, and K. Folkers. 1971. Synthetic thyrotropin-releasing hormone activity in men and women, specificity of action, inhibition by triiodothyronine, and activity orally. J. Med. Chem. 14: 477.

42. Shenkman, L., T. Mitsuma, and C. S. Hollander. 1973. Modulation of pituitary responsiveness to thyrotropinreleasing hormone by triiodothyronine. J. Clin. Invest. $52: 205$. 